\title{
PENGEMBANGAN MULTIMEDIA INTERAKTIF PADA MATERI UNSUR SEBAGAI MEDIA PEMBELAJARAN UNTUK SISWA TUNARUNGU DI SMALB
}

\author{
DEVELOPMENT OF INTERACTIVE MULTIMEDIA ON \\ ELEMENT MATERIAL AS A LEARNING MEDIA FOR \\ DEAF STUDENTS IN SMALB
}

Nikke Ardilah Wulandari dan *Sukarmin

Jurusan Kimia FMIPA Universitas Negeri Surabaya

e-mail: sukarmin@unesa.ac.id

\begin{abstract}
Abstrak
Penelitian ini bertujuan untuk mengetahui kelayakan Multimedia Interaktif (MMI) yang dikembangkan dapat digunakan sebagai media pembelajaran untuk siswa tunarungu SMALB khususnya pada materi unsur. Metode penelitian menggunakan Research and Development (R\&D) dibatasi pada tahap uji coba terbatas. Instrumen yang digunakan pada penelitian adalah lembar telaah, validasi, angket respon siswa dan aktivitas writing to learn (WTL). Metode pengumpulan data terdiri atas angket dan observasi yang selanjutnya akan dianalisis secara deskriptif. MMI dikatakan layak apabila mendapat persentase $\geq 61 \%$ dengan kriteria baik atau sangat baik. Hasil penelitian secara teoritis maupun empiris menunjukkan MMI yang dikembangkan layak digunakan sebagai media pembelajaran. Secara teoritis kelayakan didasarkan pada hasil validasi MMI yang terdiri atas kriteria isi yang memperoleh persentase degan 75,00\% 91,67\%, kriteria penyajian memperoleh persentase dengan rentang 75,00\% - 91,67\%, dan kriteria kebahasaan yang mendapat persentase dengan rentang 83,33\% - 91,67\%. Berdasarkan hasil validasi, secara teoritis MMI yang dikembangkan layak digunakan sebagai media belajar dengan kriteria baik dan sangat baik. Kelayakan MMI secara empiris yang didasarkan pada hasil angket respon siswa dengan rentang persentase $66,67 \%$ - 100\% masuk dalam kriteria baik dan sangat baik, aktivitas WTL yang mendapat nilai dengan rentang 77,78\% - 92,59\% dinyatakan layak dengan kriteria baik dan sangat baik.
\end{abstract}

Kata kunci: Tunarungu, MMI, writing to learn.

\begin{abstract}
This research aimed to know feasibility of develop Interactive Multimedia (MMI) to use as learning media for hearing-impaired students at SMALB especially for element material. Method used in this research was Research and Development $(R \& D)$ limited to the trial stage. The instruments used in the research were study sheets, validation, student questionnaire responses and writing to learn (WTL) activities. Data collection methods consisted of questionnaires and observations that would be analyzed descriptively. MMI is considered to be feasible if it gets a percentage of $\geq 61 \%$ with good or very good criteria. The theoretical and empirical research results showed that the developed MMI was worthy for the use as a learning medium. Theoretically, the eligibility was based on the results of MMI validation consisting of content criteria that obtained a percentage of $75.00 \%-91.67 \%$, the presentation criteria obtain a percentage ranging from $75.00 \%-91.67 \%$, and linguistic criteria that obtained a percentage with range $83.33 \%$ - 91.67\%. Based on the results of the validation, theoretically, the MMI developed was suitable to use as a learning media categorized in good and very good criteria. The eligibility of MMI empirically based on the results of student questionnaire responses with a range of percentage $66.67 \%$ - 100\% included in good and very good criteria, WTL activities that obtained range of $77.78 \%$ $92.59 \%$ were considered eligible categorized in good and very good criteria.
\end{abstract}

Key words: Deaf, MMI, Writing to learn.

\section{PENDAHULUAN}

Pendidikan adalah hak dasar setiap manusia, kaya, miskin, tua dan anak-anak. Undang-Undang
Dasar Negara Republik Indonesia Pasal 31 menyatakan setiap warga negara mempunyai kesempatan yang sama untuk mendapatkan 
pendidikan dan pemerintah menyelenggarakan sistem pengajaran nasional. Pendidikan tidak terbatas pada anak-anak yang normal. Anak yang mempunyai kebutuhan khusus memiliki hak yang sama, salah satunya anak tunarungu [1]. Tunarungu merupakan salah satu gangguan pada indera pendengaran. Siswa yang kehilangan sebagian pendengarannya akibat kurang berfungsinya sebagian indera pendengaran sehingga mereka kesulitan dalam pengembangan bahasa [2]. Tunarungu secara pedagogis adalah kurang atau menghilangnya pendengaran mengakibatkan hambatan perkembangan diri sehingga membutuhkan bimbingan dan kebutuhan khusus [3]. Ini menjadikan siswa tunarungu harus membutuhkan bimbingan dan perhatian yang lebih dari siswa tanpa kebutuhan khusus untuk memperoleh pendidikan yang layak. Pendidikan khusus dapat diperoleh siswa melalui Sekolah luar Biasa (SLB) dan Sekolah Inklusi.

Kurikulum SMALB salah satu mata pelajaran yang memiliki persentase lebih banyak adalah pelajaran IPA. Sebanyak 50\% dari ruang lingkup pelajaran IPA di SMA/MA ditetapakan dalam pendidikan di SMALB, akan tetapi tidak dibagi secara khusus melainkan disatukan dalam satu mata pelajaran yaitu IPA dan dengan porsi materi masing-masing [4].

Studi lapangan yang dilakukan di lembaga pendidikan yaitu Sekolah Luar Biasa (SLB) Karya Mulya Surabaya yang menampung siswa tunarungu mulai dari jenjang Taman Kanak Kanak, SD, SMP dan SMALB, Pembagian alokasi waktu pengajaran yang ada di SMALB Karya Mulya ini lebih diutamakan keterampilan hampir 70\% dibanding dengan pelajaran kognitif yang hanya $30 \%$.

Hasil angket yang disebar sebelum penelitian kepada siswa tunarungu diketahui bahwa siswa sangat menyukai pelajaran IPA dengan $58 \%$ menyukai materi kimia. Sebanyak $67 \%$ proses pembelajaran menggunakan video dan gambar dapat membantu dan menarik perhatian siswa dalam memahami materi kimia. Untuk materi kimia, sebanyak $67 \%$ siswa menganggap materi unsur sulit untuk dipelajari.

Upaya yang dilakukan untuk mempermudah siswa belajar materi unsur yaitu memfasilitasi siswa dengan media pembelajaran yang memenuhi kebutuhan siswa untuk memahami materi. Media merupakan alat untuk berinteraksi saat belajar mengajar yang berupa manusia, benda maupun peristiwa yang terjadi dan dapat menghasilkan pengetahuan, keterampilan dan sikap tertentu bagi siswa. Media penting untuk menunjang kegiatan pembelajaran menarik dan siswa terlibat secara langsung untuk berinteraksi dengan media dan harus disesuaikan dengan kebutuhan siswa [5].

Multimedia Interaktif (MMI) merupakan salah satu media untuk mengatasi keterbatasan siswa tunarungu dalam pembelajaran. MMI merupakan kumpulan jenis - jenis media anatar lain tulisan, animasi, gambar, audio dan video yang digabungkan menjadi satu dan terdapat interaksi antara komputer dengan pengguna maupun dari pengguna terhadap komputer. MMI mampu menunjang konsep materi yang dipelajari oleh siswa tunarungu [6]. Interaksi antara media terhadap pengguna ditunjukkan dengan perintah dan kegiatan yang diberikan oleh MMI namun interaksi antara pengguna terhadap media akan terbatas ketika ditujukan untuk siswa tunarungu, sehingga harus ada cara untuk mengungkapkan interaksi siswa terhadap media [1].

Cara untuk mengekspresikan apa yang dialami siswa tunarungu adalah menulis. Strategi writing to learn dapat memfasilitasi siswa untuk belajar dengan mengeksporasi, mengklarifikasi dan berfikir untuk mengungkapkan ide. Strategi WTL telah terbukti untuk membantu siswa tunarungu dalam belajar konsep ilmu pengetahuan, namun tidak spesifik untuk konsep pada materi kimia [7].

Berdasarkan latar belakang tersebut, dibutuhkan proses belajar IPA yang memberikan pengalaman belajar siswa khususnya pada materi kimia unsur dengan media interaktif yang membuat siswa dapat berinteraksi secara langsung, sehingga MMI pada materi unsur yang layak digunakan siswa tunarungu perlu dikembangkan. Permasalahan yang ada dalam penelitian ini adalah Bagaimana kelayakan MMI pada materi unsur sebagai media pembelajaran untuk siswa tunarungu di SMALB yang ditinaju dari validitas teoritis meliputi kriteria isi, kebahasaan, dan penyajian. Permasalahan 
selanjutnya bagaimana kelayakan MMI pada materi unsur sebagai media pembelajaran untuk siswa tunarungu di SMALB yang ditinjau dari validitas empiris meliputi respon siswa dan aktivitas siswa.

\section{METODE}

Desain yang digunakan pada penelitian ini adalah penelitian dan pengembangan atau $R \& D$ menurut Sukmadinata [8]. Penelitian terbatas pada tahap pengembangan uji coba terbatas. Sebanyak enam siswa Tunarungu SMALB Karya Mulya Surabaya dijadikan sebagai subyek penelitian. Kelayakan MMI akan divalidasi oleh 1 orang dosen jurusan kimia FMIPA, 1 orang dosen jurusan PLB, dan 1 orang guru IPA. Penelitian ini terdiri atas dua tahapan, yaitu: tahap pendahuluan dan pengembangan. Penjelasan untuk setiap tahap sebagai berikut:

\section{Tahap Pendahuluan}

Tahap Pendahuluan adalah tahap permulaan pengembangan produk. Pada tahap pendahuluan dibagi menjadi 3 bagian yaitu studi pustaka, survei lapangan dan menyusun draf produk.

a. Studi Pustaka

Tahap studi pustaka bertujuan menemukan konsep yang akan memperkuat produk yang dikembangkan dengan menganalisis jurnal dan mengkaji buku - buku yang relevan.

b. Studi Lapangan

Tahap studi lapangan bertujuan mengumpulkan data yang terjadi di lapangan dan selanjutnya akan digunakan untuk menyusun produk awal MMI yang akan dikembangkan.

c. Penyusunan produk awal

Tahap penyusunan awal model produk yang dikembangkan yaitu merancang MMI dengan membuat desain dalam bentuk storyboard dari produk yang akan dikembangkan. Pada penyusunan MMI terbagi menjadi tiga yaitu bagian pendahuluan, bagian isi dan bagian penutup.

\section{Tahap Pengembangan}

Pada tahap ini dilakukan pengembagan MMI sebagai media pembelajaran dengan strategi WTL yaitu creative piece dan guided free writing. Pada pengembangan MMI yang akan diuji coba terbatas kepada siswa tunarungu dilakukan pada topik utama yaitu unsur.

Data yang didapatkan dari hasil penelitian dilakukan analisis secara deskriptif kuantitatif. Data hasil telaah terhadap MMI yang dikembangkan dianalisis secara deskriptif kemudian diterapkan dalam revisi atau perbaikan sebelum dilakukan validasi.

Analisis validasi dilakukan terhadap setiap aspek yang bersangkutan dengan kelayakan isi, penyajian, kebahasaan dan kualitas multimedia ineraktif. Persentase dari data validasi ini didapatkan dari perhitungan skala Likert seperti pada Tabel 1.

Tabel 1. Skor Skala Likert

\begin{tabular}{cc}
\hline Kriteria & Nilai \\
\hline Kurang sekali & 0 \\
Kurang & 1 \\
Cukup & 2 \\
Baik & 3 \\
Sangat Baik & 4
\end{tabular}

[9]

Persentase kelayakan dihitung menggunakan rumus sebagai berikut:

Persentase $(\%)=\frac{\text { total skor pengumpulan data }}{\text { skor kriteria }} \times 100$

Dengan skor kriteris sebagia berikut:

Skor Kriteria $=$ Skor tertinggi $\mathrm{x} \Sigma$ item $\mathrm{x} \Sigma$ responden

Lembar instrumen validasi yang sudah dianalisis digunakan untuk mengetahui kelayakan media interaktif diinterpretasi skor yang terlihat pada Tabel 2.

Tabel 2. Interpretasi Skor Skala Likert

\begin{tabular}{cc}
\hline Kriteria & Persentase (\%) \\
\hline Kurang sekali & $0-20$ \\
Kurang & $21-40$ \\
Cukup & $41-60$ \\
Baik & $61-80$ \\
Sangat Baik & $81-100$
\end{tabular}

Berdasarkan interpretasi skor Tabel 2, MMI yang dikembangkan dikategorikan layak dengan persentase $\geq 61 \%$ [9].

Data aktivitas WTL dianalisis menggunakan perhitungan persentase Skala Likert seperti pada 
Tabel 1. Perhitungan persentase digunakan rumus yang sama dengan persentase kelayakan.

Berdasarkan kriteria interpretasi skor pada Tabel 2 aktivitas WTL pada MMI dikatakan layak apabila mendapatkan nilai $\geq 61$ [9].

Data hasil angket respon siswa dianalisis berdasarkan Skala Guttman. Kriteria skala yang digunakan untuk menilai angket dapat dilihat pada Tabel 3.

Tabel 3. Kriteria Skala Guuttman

\begin{tabular}{cc}
\hline Kriteria & Persentase (\%) \\
\hline Baik Sangat & $61-80$ \\
Baik & $81-100$
\end{tabular}

Persentase dihitung berdasarkan rumus seperti pada persentase kelayakan. Hasil dari analisis respon siswa dihitung dan diinterpretasikan ke dalam kriteria pada Tabel 2.

\section{HASIL DAN PEMBAHASAN}

Validasi MMI yang dikembangkan dilakukan oleh satu dosen pendidikan kimia, satu dosen jurusan PLB dan satu guru IPA SMALB. Validasi MMI meliputi kriteria isi, penyajian dan kebahasaan. MMI dinyatakan layak apabila persentase yang diperoleh $\geq 61 \%$. Hasil validasi terhadap kriteria aspek ditunjukkan pada Tabel 4.

Tabel 4. Hasil Validasi

\begin{tabular}{cc}
\hline Aspek & Persentase (\%) \\
\hline Isi & $75,00-91,67$ \\
Kebahasaan & $83,33-91,67$ \\
Penyajian & $75,00-91,67$ \\
\hline
\end{tabular}

Berdasarkan data hasil validasi Tabel 4, kriteria isi memperoleh persentase 75,00\% 91,67\% masuk kategori layak mendapat kriteria baik dan sangat baik. Aspek kebahasaan mendapatkan rentang persentase $83,33 \%-91,67 \%$ masuk kategori layak dengan kriteria sangat baik. MMI yang dikembangkan dinilai sudah menggunakan tata bahasa dan ejaan yang selaras dengan kaidah Bahasa Indonesia yang baik dan benar. Hal tersebut sesuai dengan keadaan anak tunarungu memiliki kelemahan dalam pendengarannya yang membuat anak mengalami kesulitan untuk mendapatkan informasi, akibatnya perkembangan bahasanya akan terhambat [2] .
Aspek penyajian mendapatkan persentase $75,00 \%$ - 91,67\% masuk kategori layak dengan kriteria baik dan sangat baik. Interaktif akan terlihat ketika ada sebuah perintah dalam bentuk tulisan, gambar ataupun suara mampu membuat pengguna mengikuti perintah yang diinginkan dalam media secara mandiri [1]. Secara teoritis, keseluruhan MMI yang dikembangkan masuk kategori layak dengan kriteria baik dan sangat baik.

Data hasil aktivitas WTL yang terdapat dalam MMI meliputi guided free writing dan creative peace yang terdiri dari beberapa bagian. Data hasil tersebut digunakan untuk mengetahui kelayakan secara empiris. Aktivitas WTL dinyatakan layak apabila siswa mendapat nilai $\geq 61$. Hasil aktivitas WTL setiap sisiwa disajikan pada Tabel 5.

Tabel 5. Hasil Aktivitas WTL

\begin{tabular}{ccc}
\hline Subyek & Persentase $\mathbf{( \% )}$ & Kriteria \\
\hline SF & 95,59 & Sangat Baik \\
RN & 88,89 & Sangat Baik \\
IA & 88,89 & Sangat Baik \\
MF & 77,78 & Baik \\
CD & 88,89 & Sangat Baik \\
YN & 85,19 & Sangat Baik \\
\hline
\end{tabular}

Berdasarkan hasil tersebut aktivitas WTL yang dilakukan oleh semua subyek mendapatkan rentang persentase 77,78\% - 95,59\% masuk kategori layak dengan satu subyek mendapat kriteria baik dan lima subyek mendapat kriteria sangat baik. Hal ini sesuai bahwa menulis untuk belajar merupakan strategi terbaik untuk mengajarkan siswa tunarungu tentang konsepkonsep kimia yang disesuaikan dengan kebutuhan siswa [5].

Kelayakan MMI secara empiris diperoleh dari data respon siswa. Hasil respon siswa disajikan pada tabel 6 .

Tabel 6. Hasil Respon Siswa

\begin{tabular}{clc}
\hline No. & Aspek yang dinilai & Persentase (\%) \\
\hline 1. & $\begin{array}{l}\text { MMI media yang } \\
\text { menyenangkan }\end{array}$ & 100 \\
2. & $\begin{array}{l}\text { MMI memudahkan } \\
\text { untuk mempelajari }\end{array}$ & 83,33 \\
3. & $\begin{array}{l}\text { materi unsur } \\
\text { Bahasa pada MMI }\end{array}$ & 83,33 \\
\hline
\end{tabular}




\begin{tabular}{clc}
\hline No. & \multicolumn{1}{c}{ Aspek yang dinilai } & Persentase (\%) \\
\hline 4. & $\begin{array}{l}\text { Penyajian teks, gambar } \\
\text { dan video pada MMI }\end{array}$ & 83,33 \\
yang selaras & 100 \\
5. & $\begin{array}{l}\text { Petunjuk yang ada pada } \\
\text { MMI mudah dipahami } \\
\text { Dapat mengerjakan } \\
\text { pertanyaan yang } \\
\text { disajikan }\end{array}$ & 83,33 \\
7. & $\begin{array}{l}\text { Dapat } \\
\text { mengelompokkan unsur } \\
\text { logam dan bukan logam } \\
\text { Dapat memahami sifat } \\
\text { unsur logam dan bukan } \\
\text { logam } \\
\text { Dapat memahami } \\
\text { proses pembuatan } \\
\text { kembang api } \\
\text { Memahami manfaat dan } \\
\text { bahaya unsur di } \\
\text { lingkungan sekitar }\end{array}$ & 100 \\
\hline
\end{tabular}

Berdasarkan angket respon siswa terhadap pengembangan MMI didapatkan hasil penilaian dengan rentang 83,33\% - $100 \%$ yang masuk kategori layak kriteria sangat baik, sementara dua aspek yang mendapat nilai $66,67 \%$ termasuk kriteria baik. Hal ini dikarenakan pada pada aspek tersebut lebih berisi pejelasan yang membuat subyek lebih sulit memahami. Secara keseluruhan berdasarkan angket respon siswa MMI layak digunakan sebagai media belajar siswa tunarungu.

Ditinjau dari hasil aktivitas WTL dan respon siswa, secara empiris kelayakan MMI dikatakan layak dengan kriteria baik dan sangat baik.

\section{Keterangan tiap subyek}

\section{1) $\mathrm{SF}$}

SF adalah salah satu subyek perempuan. Orang tua SF tidak mengalami ganngguan pendengaran sedikitpun (normal). SF mengalami gangguan pendengaran saat kelahiran (natal) karena ia mengalami tunarungu sejak lahir. Dalam kehidupan sehari-hari SF menggunakan kata kata dengan gerak bibir dan bahasa syarat untuk berkomunikasi dengan orang yang tidak mengalami gangguan pendengaran. Hal ini karena anak tunarungu berkomunikasi dengan memperhatikan gerak bibir lawan bicara dan tulisan [10]
Selama penelitian SF melakukan semua aktivitas WTL yang ada pada MMI dengan baik. Ini dibuktikan dengan penilaian yang dilakukan pada aktivtas WTL, SF mendapatkan nilai tertinggi. Pada beberapa bagian Creative piece, $\mathrm{SF}$ sedikit mengalami kesulitan untuk mengingat dan memahami video. SF termasuk subyek yang antusias menggunakan MMI

\section{2) $\mathrm{RN}$}

RN merupakan salah satu subyek yang memiliki gangguan pendengaran pada usia 2 tahun. orang tua RN tidak mengalami gangguan pendengaran sedikitpun (normal). Dalam kehidupan sehari-hari RN melakukan komunikasi dengan orang yang tidak mengalami gangguan menggunakan bahasa Indonesia dan bahasa isyarat.

Selama penelitian RN salah satu subyek yang antusias, ia akan bertanya jika mengalami kesulitan dalam neggunakan media. RN melakukan semua aktivitas WTL yang ada pada MMI dengan baik. Meskipun ada beberapa dari aktivitas WTL bagian creative peace yang dianggap RN sulit untuk dipahami. Sama seperti SF, subyek RN antusias menggunakan MMI.

3) IA

IA merupakan anak yang lahir ddari orang tua yang tidak memiliki gangguan pendengaran sedikitpun (normal). IA satu - satunya dari anggota keluarga yang mengalami tunarungu. Pada jenjang pendidikan SD dan SMP IA masih belajar di sekolah normal dan baru mengikuti pendidikan khusus pada jenjang SMA. IA masih dapat berkomunikasi bersama teman - temannya dengan alat bantu pendengaran.

Dalam kehidupan sehari-hari IA berkomunikasi dengan bahasa Indonesia dan bahasa isyarat. Sedangkan melakukan komunikasi dengan orang yang tidak mengalami gangguan pendengaran (normal) IA lebih mudah membaca gerak bibir dan bahasa isyarat.

Selama penelitian IA salah satu subyek yang antusias. Namun berbeda dengan subyek RN, Subyek IA tidak bertanya secara langsung dan lebih memilih melihat temannya saat mengalami kesulitan. IA melakukan semua aktivitas WTL yang ada pada MMI dengan baik. Kesulitan 
aktivitas WTL yang dialami oleh IA sama seperti RN. Selain aktivitas WTL, IA mengalami kesulitan untuk mengingat materi yang sudah dipelajari sebelumnya.

\section{4) $\mathrm{MF}$}

Subyek MF merupakan anak tungal dari orang tua yang tidak mengalami gangguan pendengaran sedikitpun (normal). Sejak TK, MF sudah mengikuti pendidikan khusus, ini dikarenakan tingkat ketunarunguan yang dialami MF sudah berada pada taraf yang berat. Pendidikan di SLB yang menitikberatkan pada pelajaran bahasa, kemampuan berkomunikasi dan membaca dapat membantu anak dengan taraf ketunarunguan seperti yang dialami subyek MF ini [3].

MF seharusnya memiliki tingkat intelegensi yang lebih baik dari teman - temannya karena ia sudah mengenal bahasa meskipun hanya sedikit, ini disebabkan ketunarunguan yang dialami MF diketahui sejak usia 2 tahun. Namun pada kenyataannya, MF merupakan subyek yang sulit dalam memahami materi yang ada pada MMI. Ini dibuktikan dengan hasil aktivitas WTL yang mendapat persentase terendah.

Selama penelitian subyek MF sulit memahami materi dan lebih banyak bicara dengan temannya. Sesekali MF terlihat tidak fokus pada MMI. MF sering merasa kesulitan dalam memahami pertanyaan yang ada pada MMI.

\section{5) $\mathrm{CD}$}

Lahir dari orang tua yang tidak mengalami ganngguan pendengaran sedikitpun (normal), CD salah satu subyek laki - laki pada penelitian ini mengalami gangguan pendengaran saat kelahiran (natal) karena ia mengalami tunarungu sejak lahir.

Ketunarunguan yang dialami CD masih pada taraf ringan sehingga anak masih dapat belajar bersama teman - temannya dengan alat bantu pendengaran. Dalam kehidupan sehari-hari CD menggunakan bahasa verbal dengan membaca gerak bibir dan bahasa syarat untuk berkomunikasi dengan orang yang tidak mengalami gangguan pendengaran (normal).

Selama penelitian CD melakukan semua aktivitas WTL yang ada pada MMI dengan baik. CD sedikit mengalami kesulitan untuk memahami penulisan lambang unsur yang ada pada MMI. CD termasuk subyek yang antusias selama menggunakan MMI, namun ia lebih banyak diam selama penelitian berlangsung. Ini dikarenakan karakteristik CD yang memang dikenal sebagai anak yang pendiam diantara teman - temannya.

6) $\mathrm{YN}$

Subyek YN lahir dari orang tua normal, memiliki seorang kakak dan satu orang adik yang tidak mengalami gangguan pendengaran sedikitpun. Hanya YN anggota keluarga yang mengalami tunarungu sejak usia satu tahun.

Meskipun dalam kategori berat, namun YN masih memiliki sisa pendengaran dan lebih mudah berkomunikasi membaca gerak bibir dengan orang yang tidak mengalami gangguan pendengaran serta menggunakan bahasa isyarat jika berkomunikasi dengan teman - temannya. YN merupakan anak yang cukup pendiam namun aktif dalam pelajaran. ia menyelesaiakan aktivitas WTL dengan baik.

YN merupakan anak yang ramah dan murah senyum, ia selalu menyapa orang - orang yang ia temui. Selama penelitian YN sesekali bertanya langsung jika mengalami kesulitan. YN selalu aktif menjawab jika diberikan pertanyaan.

\section{SIMPULAN}

Berdasarkan permasalahan dan hasil penelitian, simpulan dari MMI yang dikembangkan dinyatakan layak dengan keterangan sebagai berikut:

1. Secara teoritis kelayakan MMI dilihat dari kriteria isi mendapat persentase $75,00 \%$ $91,67 \%$, penyajian mendapat persentase $75,00 \%$ - $91,67 \%$ dan kebahasaan mendapatkan persentase 83,33\% - 91,67\% sehingga MMI dapat digunakan sebagai media pembelajaran.

2. Kelayakan MMI secara empiris ditinjau dari respon siswa yang mendapat persentase $66,67 \%$ - 100\% mendapat kategori layak dengan kriteria baik dan sangat baik. Aktivitas Writing to Learn (WTL) dengan persentase antara 77,78\% - 95,59\% sehingga MMI yang dikembangkan dapat digunakan sebagai media pembelajaran. 


\section{SARAN}

Berdasarkan pembahasan, saran untuk penelitian selanjutnya adalah sebagai berikut:

1. Menerapkan MMI yang dikembangkan untuk membantu proses belajar siswa tunarungu.

2. Melengkapi MMI yang sudah dikembangkan dengan materi lain untuk

3. menunjang referensi belajar untuk siswa tunarungu.

4. Penelitian selanjutnya perlu menambah aktivitas WTL yang lain untuk melengkapi aktivitas WTL yang sudah ada di MMI yang dikembangkan.

\section{DAFTAR PUSTAKA}

1. Rivai, S.N., \& Poedjiastoetie, S. 2015. Development of Interactive Multimedia Using Writing to Learn Strategy on Electrolyte And Nonelectrolyte Solution Topic for Deaf Senior High And Vocational School Student in Inclusive Class. Unesa Journal Of Chemical Education. Vol. 4, No. 2, Hal.378-385.

2. Somantri, S. 2006. Psikologi Anak Luar Biasa. Bandung : PT Refika Aditama Menteri Pendidikan dan Kebudayaan RI.

3. Sastrawinata, E., Salim, M., \& Sugiarto, M. 1977. Pendidikan Anak Tunarungu. Jakarta: Departemen Pendidikan Dan Kebudayaan.
4. Depdiknas. 2006. Kurikulum Tingkat Satuan Pendidikan. Jakarta: Depdiknas

5. Larasati, L.D., \& Poedjiastoeti, S. 2016. Pengembangan Permainan Kartu Domino Kimia Sebagai Media Pembelajaran Pada Materi Unsur Bagi Siswa SMALB Tunarungu. Unesa Journal of Chemical Education Vol.3, No.1, Hal.115-119.

6. Poedjiastoeti, S., \& Liliasari. 2009. Karateristik Kit Kimia "Unsur, Senyawa, Dan Campuran" Untuk Siswa SMALB-B. Prosiding Seminar Nasional Penelitian, Pendidikan dan Penerapan MIPA.

7. Marschark, M., Lang, H.G., \& Albertini, J.A. 2002. Educating Deaf Students: From Research to Practice. New York: Oxford University Press, Inc.

8. Sukmadinata, N.S. 2012. Metode Penelitian Pendidikan. Bandung: PT. Remaja Rosdakarya.

9. Riduwan. 2015. Skala Pengukuran Variabel - Variabel Penelitian. Bandung: Alfa-Beta.

10. Permendiknas. 2009. Salinan Peraturan Menteri Pendidikan nasional Nomor 70 Tahun 2009 Tentang Pendidikan Inklusif Bagi Peserta Didik Yang Memiliki Kelainan Dan Memiliki Potensi Kecerdasan Dan/Atau Bekat Istimewa. Jakarta: Departemen Pendidikan Nasional. 